\title{
Effect of Plant Spacing on Yield and Some Quality Characteristics of Three Chickpea (Cicer arietinum L.) Varieties
}

\author{
Sumaya A. Abdullah', Bilal I. Mohammed ${ }^{2 *}$, Raad H. Salih ${ }^{1}$ \\ ${ }^{1}$ Department of Field Crops, College of Agriculture, University of Salahaddin, Erbil, Kurdistan Region - F.R. Iraq, ${ }^{2}$ Department of Field Crops, \\ Khabat Technical Institute, Erbil Polytechnic University, Erbil, Kurdistan Region - F.R. Iraq
}

\section{${ }^{*}$ Corresponding author: \\ Bilal I. Mohammed, \\ Department of Plant Production, Khabat Technical Institute, Erbil Polytechnic University, Erbil, Kurdistan Region - F.R. Iraq. Phone: 7504699939. \\ E-mail: bilal.muhammed@epu. edu.iq}

Received: 02 May 2018

Accepted: 04 September 2018

Published: 30 June 2019

DOI

10.25156/ptj.v9n1y2019.pp37-42

\section{A B S TRACT}

A field study was conducted at Grdarasha Research Station of the College of Agriculture/Salahaddin University, Erbil, during growing winter season of 2017, to study the effect of plant spacing on some yield and quality of chickpea varieties. The factorial experiment was applied in "Randomized Complete Block Design" (RCBD), in three replicates, by using four plant spacing (6, 9, 12 and 15 $\mathrm{cm}$ ), and three varieties of chickpea (Rafedain, Gab and TH85) were implemented. The $15 \mathrm{~cm}$ plant spacing produced the highest number of primary branches per plant (4.34), number of pods per plant (15.44), seed yield (1124.33 kg/ha), protein percentage (23.12), protein yield $(247.19 \mathrm{~kg} / \mathrm{ha})$, and oil percentage (11.81). On the contrary, the $6 \mathrm{~cm}$ plant spacing recorded the highest value of carbohydrate percentage (60.91); also, Gab variety exceeds Rafedain and TH85 varieties in number of primary branch per plant (4.07), number of pods per plant (11.71), seed yield (1120.91 kg/ha), protein percentage (22.25), and protein yield $(250.26 \mathrm{~kg} / \mathrm{ha})$, but the TH85 gave the optimum oil percentage (11.14) and carbohydrate percentage (59.84). From the interaction of plant spacing with varieties, the highest rate was recorded at $15 \mathrm{~cm}$ plant spacing with Gab variety seed yield $(1192.85 \mathrm{~kg} / \mathrm{ha})$ and protein yield $(297.16 \mathrm{~kg} / \mathrm{ha}$ ). There was a positive and negative correlation between yield and number of pods per plant and number of seeds per pod ( $r=0.673$ and 0.689$)$ and between carbohydrate percentage with protein and oil percentages $(r=-0.777$ and -0.658$)$, respectively.

Keywords: Chickpea; Plant spacing; Yield and yield component

\section{INTRODUCTION}

Chickpea (Cicer arietinum L.) belongs to the family Fabaceae, an annual and one of the important pull crops. Chickpea is one of the important pulse crops, which contains high protein and starch percentage, and it is very important for in human nutrition. Cicer suitable for region with warm weather and semi-dry conditions, in addition to having high-protein content $(20-22 \%)$ and rich in fiber and minerals, and it is the fourth-largest grain legume crops in the world, with a total production of 10.9 million tons from an area of 12.0 million ha, a productivity of $0.91 \mathrm{t} / \mathrm{ha}$. Major producing countries are India, Pakistan, and Iran (FAO, 2016). Chickpea being a leguminous crop improves soil fertility by fixing atmospheric nitrogen up to $99 \mathrm{~kg} / \mathrm{ha}$ in available from $\mathrm{NH}_{3}$ and $\mathrm{NH}_{4}$ in the root through the phenomena of symbiosis (Schwenke et al., 1998). Among the various agronomic practices, plant density is one of the most important agronomic factors that have a great impact on growth and yield, high density initially provokes fast growth of canopy in area unit which, in turn, ejects available stored water in soil through perspiration and causes the plant to encounter drought stress during flowering and grain filling stages; therefore, under rainfed conditions, suitable seed density must be considered for more absorption of solar energy and improved utilization of water and soil (ICARDA, 1990). The increased seed yield with higher plant density is largely due to improved water use and water use efficiency. The use of high plant density in chickpea production decreases soil water evaporation early in the growing season when plant canopy closure is low; in contrast, low plant density may allow weeds to develop more aggressively and limit crop yield potential. Plants grown at lower plant density are usually shorter and branchy, which increases losses during combine harvest (Turner et al., 2001). Seddique and Sedgeley (1985) revealed that the branch number of chickpea is affected by plant density and, thus, chickpea has a lower branch in high densities. Therefore, it is possible to obtain the maximum grain yield by managing the planting density to increase the main stem number and reducing the branch number per unit area. Ali et al. (1999) reported that increase of plant spacing significantly increased the plant height, number of pods per plant and seed yield, and the 
wider plant spacing of $15 \mathrm{~cm}$ produced greater number of pods per plant (81.7) followed by 10 and $5 \mathrm{~cm}$ plant spacing with 74.2 and 68.2 pods per plant, respectively, results further indicated that wider plant spacing 15 and $10 \mathrm{~cm}$ caused significantly higher yield of 16.2 and $14.2 \mathrm{~g} /$ plant, respectively. Cultivar and planting densities are important factors affecting the growth and grain yield of chickpea (Stieller et al., 1994). It has been reported that the density of 28 plant $\mathrm{m}^{-2}$ is the optimum density for chickpea cultivated under irrigated conditions in cold climates (Shams et al., 2005). Kanooni (2013) evaluated the grain yield of two chickpea genotypes in 25,35 , and 45 plant $\mathrm{m}^{-2}$ in a dryland farming system in the dry moderate region; in this research, the chickpea genotypes produced the highest grain yield in the density of 45 plant $\mathrm{m}^{-2}$. According to Singh et al. (2011), more number of branches, number of pods per plant, 100 grains weight, and yield were produced by dense and semi-extensive varieties with low density together with high pod erect growing varieties with high density. The objective of this study is to reevaluate the response of three chickpea varieties to different plant spacing on yield, yield components, and some quality characteristics in Kurdistan region.

\section{MATERIALS AND METHODS}

A field study was conducted at the Grdarasha Research Station of the College of Agriculture/Salahaddin University, Erbil (latitude $36^{\circ} 4^{\prime} \mathrm{N}$ and longitude $44^{\circ} 2^{\prime} \mathrm{E}$ ) $415 \mathrm{~m}$ above sea level having annual rainfall (250-600 mm) during growing winter season of 2017 to study the effect of plant spacing on yield and some quality characteristics of chickpea varieties.

The factorial experiment was applied in "Randomized Complete Block Design" (RCBD), in three replicates, by using four plant spacing $(6,9,12$ and $15 \mathrm{~cm})$, and three varieties of chickpea (Rafedain, Gab and TH85) were implemented. The representative soil samples were taken from various locations of the field at depth of $0-30 \mathrm{~cm}$ after tillage. These samples were air-dried then sieved using $2 \mathrm{~mm}$ sieve, then packed for analysis.

An experimental unit size $(2 \mathrm{~m} \times 2 \mathrm{~m})$ was used consisting of six rows (with $30 \mathrm{~cm}$ row spacing). Sowing was done manually on the first of March and two seeds were placed in each hole percentage germination of sowing depth of $3 \mathrm{~cm}$ and distributed according to plant density combination [Table 1]. Five plants were randomly selected from each experimental unit to study the quantitative characteristics: Plant height $(\mathrm{cm})$, number of primary branches plant ${ }^{-1}$, number of pods plant ${ }^{-1}$, number of seeds $\operatorname{pod}^{-1}$, and the 100 seed weight $(\mathrm{g})$ and were calculated. All middle line plants of each experimental unit were harvested to calculated yield $(\mathrm{kg} / \mathrm{ha})$ and qualitative characteristics: Protein percentage, protein yield, oil percentage, and carbohydrate percentage.

The data were statistically analyzed for all of the studied traits according to the analysis of variance using the Statistical Analysis System (SAS Institute, 2005). Duncan's multiple range test at 5\% level was used to determine among means (Steel and Torrie, 1997). Simple correlation coefficient was calculated between the seed yield and other traits, and among the traits themselves and simple regression among some studied traits (Al-Rawi, 1984).

\section{RESULTS AND DISCUSSION}

\section{Number of Primary Branches Plants ${ }^{-1}$}

Table 2 shows the effect of plant spacing, varieties, and their interaction for components analysis of chickpea. The maximum no. of primary branch registers in $15 \mathrm{~cm}$ plant spacing (4.34) whereas the minimum was for $6 \mathrm{~cm}$ plant spacing which was (2.94). Among the various agronomic practices, plant density is one of the most important agronomic factors that have great impact on number of primary branches; Seddique and Sedgeley (1985) revealed that the branch number of chickpea is affected by plant density and also Singh et al. (1988) have examined the effects of density on the number of branches and stated that the number of branches decreases with the increase in density. However, the different varieties, Gab variety obtained significantly higher number of primary branches followed by Rafedain variety. The highest value was at $15 \mathrm{~cm}$ plant spacing with Gab variety (4.66), but the lower value was recorded for Rafedain variety when planted at $6 \mathrm{~cm}(2.47)$.

\section{Number of Pods/Plant}

The results of number of pods plant ${ }^{-1}$ are displayed in Table 2. A wide variation was observed in these results, the highest number of pods plant ${ }^{-1}$ was at $15 \mathrm{~cm}$ plant spacing

Table 1: Plant density combinations (intrarow spacing)

\begin{tabular}{|c|c|c|c|c|}
\hline Row spacing (cm) & Plant spacing $(\mathrm{cm})$ & One plant area $\left(\mathrm{cm}^{2}\right)$ & Number of plants $\mathrm{m}^{-2}$ & Number of plants ha-1 \\
\hline 30 & 6 & 180 & 55.55 & 555,555 \\
\hline 30 & 9 & 270 & 37.03 & 370,370 \\
\hline 30 & 12 & 360 & 27.77 & 277,777 \\
\hline 30 & 15 & 450 & 22.22 & 222,222 \\
\hline
\end{tabular}


(15.44), while the lowest number was recorded at $6 \mathrm{~cm}$ plant spacing which was 8.10. The maximum was for Gab variety 11.71, whereas the minimum was for Rafedain variety (10.85). Referring back to Table 2, there was no coincidence in the results of Gab variety when planted at $15 \mathrm{~cm}$ plant spacing which also gives the highest number of pods/plant (16.33), but the lowest was 7.33 for TH85 variety when planted at $6 \mathrm{~cm}$ plant spacing. From Table 3 , there was a positive and highly significant correlation between this trait and number of primary branches per plant $\left(r=0.820^{* *}\right)$. From Figure 1a, the linear component showed a direct proportional relationship between number of primary branches per plant and the number of pods per plant according to the following equation $(\hat{Y}=5.51 \mathrm{X}+8.72)$ which means an increase of one branch per plant result increase of number of pods per plant by 5.51 pod.

Table 2: Effect of plant spacing on yield and its component of chickpea varieties

\begin{tabular}{|c|c|c|c|c|c|c|}
\hline \multicolumn{2}{|c|}{ Plant spacing (cm) } & $\begin{array}{c}\text { Number of primary } \\
\text { branches plant }^{-1}\end{array}$ & $\begin{array}{l}\text { Number of } \\
\text { pods plant }^{-1} \\
\end{array}$ & $\begin{array}{l}\text { Number of } \\
\text { seeds pod }{ }^{-1}\end{array}$ & 250 seed weight $(\mathrm{g})$ & Seed yield (kg/ha) \\
\hline \multicolumn{2}{|l|}{6} & $2.94^{d}$ & $8.10^{d}$ & $1.07^{c}$ & $49.89^{d}$ & $913.58^{d}$ \\
\hline \multicolumn{2}{|l|}{9} & $3.46^{c}$ & $9.14^{c}$ & $1.18^{c}$ & $56.56^{c}$ & $968.51^{c}$ \\
\hline \multicolumn{2}{|l|}{12} & $3.77^{b}$ & $12.40^{\mathrm{b}}$ & $1.34^{\mathrm{b}}$ & $60.21^{b}$ & $1063.45^{b}$ \\
\hline \multicolumn{2}{|l|}{15} & $4.34^{a}$ & $15.44^{\mathrm{a}}$ & $1.60^{a}$ & $69.28^{a}$ & $1124.33^{a}$ \\
\hline \multicolumn{2}{|c|}{ Varieties } & $\begin{array}{l}\text { Number of primary } \\
\text { branches plant }^{-1}\end{array}$ & $\begin{array}{l}\text { Number of } \\
\text { pods plant }^{-1}\end{array}$ & $\begin{array}{l}\text { Number of } \\
\text { seeds pod }{ }^{-1}\end{array}$ & 250 seed weight $(\mathrm{g})$ & Seed yield (kg/ha) \\
\hline \multicolumn{2}{|c|}{ Rafedain } & $3.29^{c}$ & $10.85^{c}$ & $1.35^{a}$ & $49.18^{c}$ & $985.79^{b}$ \\
\hline \multicolumn{2}{|c|}{ Gab } & $4.07^{a}$ & $11.71^{\mathrm{a}}$ & $1.31^{a, b}$ & $68.18^{a}$ & $1120.91^{\mathrm{a}}$ \\
\hline \multicolumn{2}{|c|}{ TH85 } & $3.53^{b}$ & $11.24^{\mathrm{a}, \mathrm{b}}$ & $1.23^{b}$ & $59.58^{b}$ & $945.71^{b}$ \\
\hline \multicolumn{2}{|c|}{$\begin{array}{l}\text { Plant } \\
\text { spacing } \times \text { Varieties }\end{array}$} & $\begin{array}{l}\text { Number of primary } \\
\text { branches plant }^{-1}\end{array}$ & $\begin{array}{l}\text { Number of } \\
\text { pods plant }^{-1}\end{array}$ & $\begin{array}{l}\text { Number of } \\
\text { seeds pod }{ }^{-1}\end{array}$ & 250 seed weight $(\mathrm{g})$ & Seed yield (kg/ha) \\
\hline \multirow[t]{3}{*}{6} & Rafedain & $2.47^{h}$ & $8.44^{d}$ & $1.18^{\mathrm{c}, \mathrm{d}, \mathrm{e}}$ & $42.92^{9}$ & $938.89^{c}$ \\
\hline & Gab & $3.55^{e, f}$ & $8.55^{d}$ & $1.02^{\mathrm{d}, \mathrm{e}}$ & $57.20^{d}$ & $946.33^{a, b}$ \\
\hline & TH85 & $2.81^{g, h}$ & $7.33^{\mathrm{e}}$ & $1.00^{e}$ & $49.55^{e}$ & $1048.15^{\mathrm{a}, \mathrm{b}, \mathrm{c}}$ \\
\hline \multirow[t]{3}{*}{9} & Rafedain & $3.21^{\mathrm{f,g}}$ & $9.11^{d}$ & $1.28^{b, c, d}$ & $46.55^{\dagger}$ & $1136.51^{\mathrm{a}, \mathrm{b}}$ \\
\hline & Gab & $3.82^{\mathrm{c}, \mathrm{d}, \mathrm{e}}$ & $8.99^{d}$ & $1.18^{\mathrm{c}, \mathrm{d}, \mathrm{e}}$ & $64.77^{c}$ & $1083.33^{a, b, c}$ \\
\hline & TH85 & $3.33^{f}$ & $9.33^{c}$ & $1.08^{\mathrm{d}, \mathrm{e}}$ & $58.36^{d}$ & $1076.18^{\mathrm{a}, \mathrm{b}, \mathrm{c}}$ \\
\hline \multirow[t]{3}{*}{12} & Rafedain & $3.44^{e, t}$ & $11.55^{\mathrm{c}}$ & $1.36^{\mathrm{b}, \mathrm{c}}$ & $48.49^{e}$ & $718.52^{\mathrm{d}}$ \\
\hline & Gab & $4.22^{\mathrm{a}, \mathrm{b}, \mathrm{c}}$ & $13.66^{b}$ & $1.34^{\mathrm{b}, \mathrm{c}}$ & $68.81^{b}$ & $1160.31^{a}$ \\
\hline & TH85 & $3.66^{\mathrm{d}, \mathrm{e}, \mathrm{f}}$ & $11.99^{c}$ & $1.34^{\mathrm{b}, \mathrm{c}}$ & $63.33^{c}$ & $911.11^{c}$ \\
\hline \multirow[t]{3}{*}{15} & Rafedain & $4.03^{b, c, d}$ & $14.33^{b}$ & $1.61^{a}$ & $58.77^{d}$ & $1077.03^{a, b, c}$ \\
\hline & Gab & $4.66^{a}$ & $16.33^{a}$ & $1.70^{\mathrm{a}}$ & $81.96^{a}$ & $1192.85^{a}$ \\
\hline & TH85 & $4.33^{\mathrm{a}, \mathrm{b}}$ & $15.66^{a}$ & $1.51^{\mathrm{a}, \mathrm{b}}$ & $67.01^{b}$ & $924.48^{c}$ \\
\hline
\end{tabular}

Means with the same letters are not significantly difference
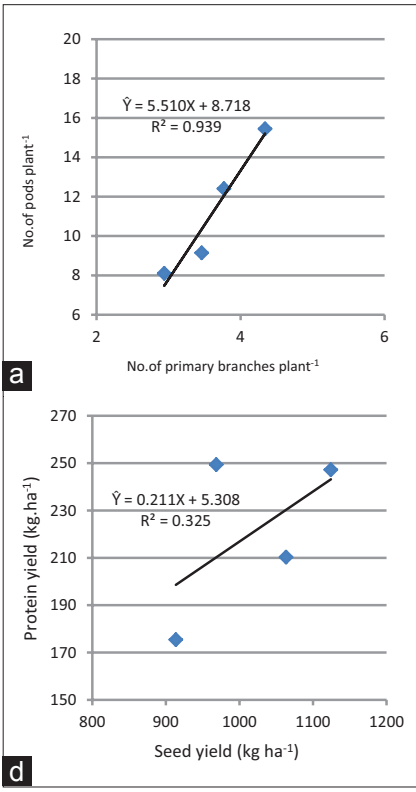
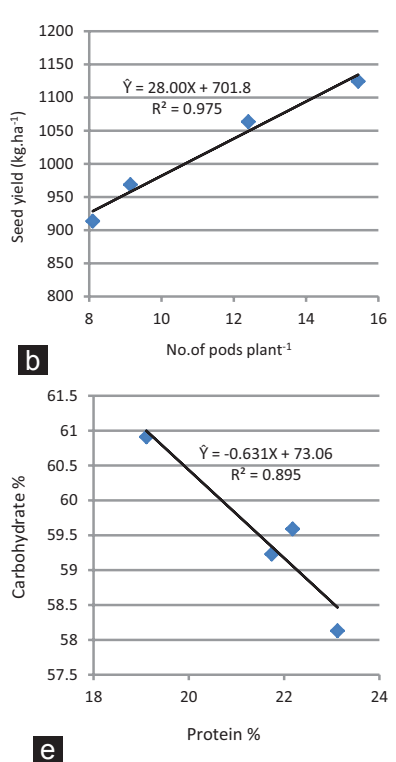

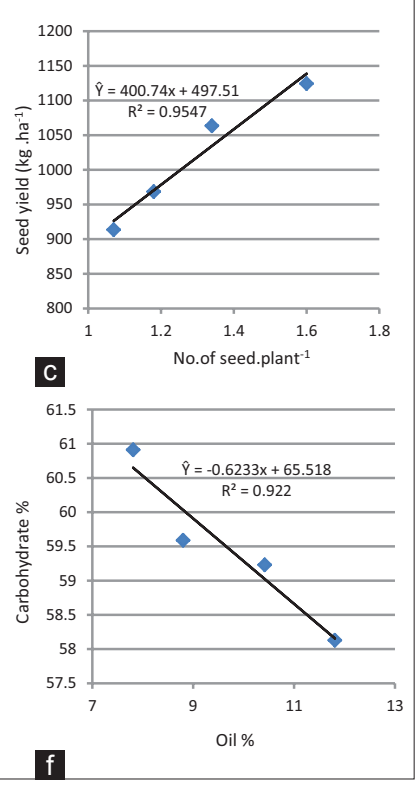

Figure 1: (a-f) Regression among some studied characteristics 


\section{Number of Seeds/Pod}

The number of seeds pod ${ }^{-1}$ is displayed in Table 2 showing that the highest was recorded for the sample collected at $15 \mathrm{~cm}$ plant spacing (1.60), whereas the sample collected at $6 \mathrm{~cm}$ plant spacing (1.07) was statistically similar to $9 \mathrm{~cm}$ plant spacing (1.18). (Singh et al., 1988) reported that increase in density affects the number of grains per plant, causing it to decrease, but the number of grains per unit area is higher in high density than low ones. Many researchers believe that increase in yield is due to increase in the number of grains (Bagheri et al., 1997). The heights number of seed per pod was obtained by Rafidain variety (1.35). Considering the interaction between plant spacing and varieties, the highest was 1.70 for Gab variety at $15 \mathrm{~cm}$ plant spacing, but the lowest value was recorded from TH85 variety at $6 \mathrm{~cm}$ plant spacing (1.00).

\section{Seed Weight $(\mathrm{g})$}

Table 2 shows the highest 250 seed weight for $15 \mathrm{~cm}$ plant spacing which was $69.28 \mathrm{~g}$, while the lowest weight was recorded at $6 \mathrm{~cm}$ plant spacing which was $49.89 \mathrm{~g}$. However, the maximum rate of varieties was at $\mathrm{Gab}$ variety $(68.18 \mathrm{~g})$ and the minimum was at Rafedain (49.18 g). The highest interaction was recorded for the sample collected from Gab variety with $15 \mathrm{~cm}$ plant spacing $(81.96 \mathrm{~g})$, but the lowest was $42.92 \mathrm{~g}$ for Rafedain variety at $6 \mathrm{~cm}$ plant spacing.

\section{Seed Yield (kg/ha)}

Table 2 displayed seed yield performed that the highest was at $15 \mathrm{~cm}$ plant spacing $(1124.33 \mathrm{~kg} / \mathrm{ha})$, while the lowest was at $6 \mathrm{~cm}$ plant spacing $(913.6 \mathrm{~kg} / \mathrm{ha})$; this variation is due to when planting chickpea by wide plant spacing $(15 \mathrm{~cm})$ leads to increase 250 seed weight and number of seed/pod and consequently resulted to increase yield components [Tables 2 and 3]. The highest value was also for Gab variety $(1120.91 \mathrm{~kg} / \mathrm{ha})$, but the lowest value was recorded for TH85 variety $(945.71 \mathrm{~kg} / \mathrm{ha})$. These variations in results, in the samples, confirm that the interaction between plant spacing and varieties is different. The optimum value was at $15 \mathrm{~cm}$ plant spacing for Gab variety $(1192.85 \mathrm{~kg} / \mathrm{ha})$, whereas the minimum was $12 \mathrm{~cm}$ plant spacing for Rafedain variety $(718.52 \mathrm{~kg} / \mathrm{ha})$. From Table 3 , there was a positive and highly significant correlation between this trait and number of pods per plant, number of seeds per pod, and 250 seed weight $\left(r=0.673^{* *}, 0.689^{* *}\right.$, and $\left.0.659^{* *}\right)$, respectively. From Figure $1 \mathrm{~b}$ and c, the linear component showed a direct proportional relationship between seed yield with number of pods per plant and number of seeds per pod according to the following equations: $\hat{Y}=28.0 X+701.9$ and $\hat{Y}=406.7 X+497.5$, respectively, which indicate that for each increase of one pod per plant and one seed per pod will result in increase in seed yield by 28.0 and $4007 \mathrm{~kg} / \mathrm{ha}$ for number of pods and number of seeds per pod, respectively.

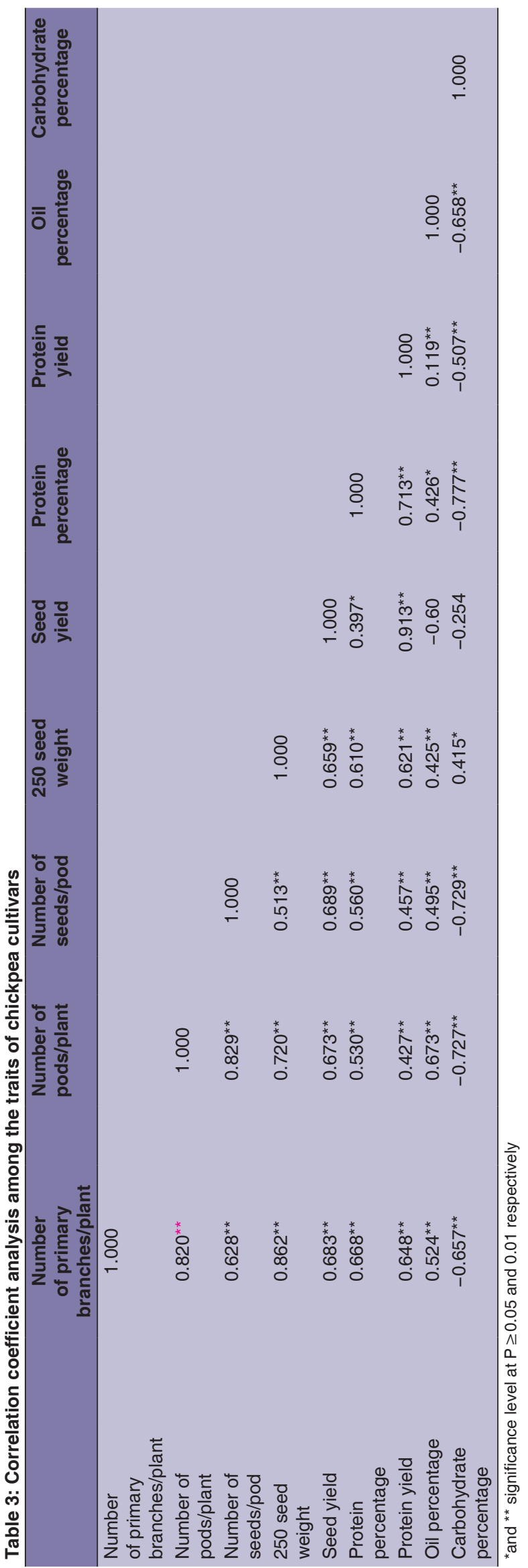


Abdullah, et al.

Table 4: Effect of plant spacing on some quality characteristics of chickpea varieties

\begin{tabular}{|c|c|c|c|c|c|}
\hline \multicolumn{2}{|c|}{ Plant spacing (cm) } & Protein (\%) & Protein yield (kg/ha) & Oil (\%) & Carbohydrate (\%) \\
\hline \multicolumn{2}{|c|}{6} & $19.11^{d}$ & $175.43^{c}$ & $7.81^{d}$ & $60.91^{a}$ \\
\hline \multicolumn{2}{|l|}{9} & $22.18^{b}$ & $249.35^{a}$ & $8.80^{c}$ & $59.59^{b}$ \\
\hline \multicolumn{2}{|c|}{12} & $21.74^{c}$ & $210.32^{b}$ & $10.42^{b}$ & $59.23^{c}$ \\
\hline \multicolumn{2}{|c|}{15} & $23.12^{\mathrm{a}}$ & $247.19^{a}$ & $11.81^{a}$ & $58.13^{d}$ \\
\hline \multicolumn{2}{|c|}{ Varieties } & Protein (\%) & Protein yield $(\mathrm{kg} / \mathrm{ha})$ & Oil (\%) & Carbohydrate (\%) \\
\hline \multicolumn{2}{|c|}{ Rafedain } & $21.36^{b}$ & $210.82^{b}$ & $9.15^{b}$ & $59.06^{c}$ \\
\hline \multicolumn{2}{|c|}{ Gab } & $22.25^{\mathrm{a}}$ & $250.26^{a}$ & $8.84^{c}$ & $59.53^{b}$ \\
\hline \multicolumn{2}{|c|}{ TH85 } & $21.07^{c}$ & $200.64^{b}$ & $11.14^{\mathrm{a}}$ & $59.84^{a}$ \\
\hline \multicolumn{2}{|c|}{ Plant spacing $\times$ Varieties } & Protein (\%) & Protein yield (kg/ha) & Oil (\%) & Carbohydrate (\%) \\
\hline \multirow[t]{3}{*}{6} & Rafedain & $17.30^{f}$ & $162.46^{\mathrm{e}}$ & $6.53^{h}$ & $61.12^{\mathrm{a}}$ \\
\hline & Gab & $20.84^{d}$ & $225.76^{b, c, d}$ & $8.33^{g}$ & $60.43^{b}$ \\
\hline & TH85 & $19.20^{\mathrm{e}}$ & $138.07^{e}$ & $8.56^{t, g}$ & $61.29^{a}$ \\
\hline \multirow[t]{3}{*}{9} & Rafedain & $22.05^{c}$ & $250.59^{b, c}$ & $8.46^{\mathrm{f}, \mathrm{g}}$ & $59.37^{e}$ \\
\hline & Gab & $22.20^{c}$ & $257.57^{\mathrm{b}}$ & $8.70^{f}$ & $59.26^{e}$ \\
\hline & TH85 & $21.75^{d}$ & $239.88^{b, c, d}$ & $9.23^{e}$ & $60.15^{c}$ \\
\hline \multirow[t]{3}{*}{12} & Rafedain & $22.21^{c}$ & $210.19^{c, d}$ & $9.30^{\mathrm{e}}$ & $58.62^{\dagger}$ \\
\hline & Gab & $21.04^{d}$ & $626.00^{d}$ & $8.70^{f}$ & $59.83^{d}$ \\
\hline & TH85 & $21.98^{c}$ & $200.24^{d}$ & $13.26^{b}$ & $59.26^{e}$ \\
\hline \multirow[t]{3}{*}{15} & Rafedain & $23.88^{b}$ & $220.04^{b, c, d}$ & $12.30^{c}$ & $57.15^{\mathrm{g}}$ \\
\hline & Gab & $24.93^{a}$ & $297.16^{a}$ & $9.63^{d}$ & $58.59^{f}$ \\
\hline & TH85 & $20.83^{d}$ & $220.65^{b, c, d}$ & $13.50^{\mathrm{a}}$ & $58.66^{\dagger}$ \\
\hline
\end{tabular}

Means with the same letters are not significantly difference

\section{Protein (\%)}

Table 4 shows the protein percentage which was the maximum level of $15 \mathrm{~cm}$ plant spacing which was $23.12 \%$ and the minimum was $6 \mathrm{~cm}$ plant spacing that was $19.11 \%$; this result is agreed with Valimohamadi et al., 2009, pointed out that at higher plant populations, competition for photoassimilates due to nitrogen deficiency caused reduction in protein content and Gab variety has the highest rate $(22.25 \%)$, whereas the interaction between plant spacing and varieties, the maximum rate was also at $15 \mathrm{~cm}$ plant spacing with Gab variety which was $24.93 \%$ and the minimum was at $6 \mathrm{~cm}$ plant spacing with Rafedain variety that was $17.30 \%$.

\section{Protein yield ( $\mathrm{kg} / \mathrm{ha})$}

The protein yield $\mathrm{kg} / \mathrm{h}$ is displayed in Table 4 shows that the highest level was observed at $9 \mathrm{~cm}$ plant spacing and $15 \mathrm{~cm}$ plant spacing which was $249.35 \mathrm{~kg} / \mathrm{ha}$ and $247.19 \mathrm{~kg} / \mathrm{ha}$ respectively, while the maximum rate of varieties was at $\mathrm{Gab}$ variety $(250.26 \mathrm{~kg} / \mathrm{ha})$ and the minimum was at Rafedain and TH85 that were $210.82 \mathrm{~kg} / \mathrm{ha}$ and $200.64 \mathrm{~kg} / \mathrm{ha}$, respectively. The plant spacing with varieties recorded the highest rate of protein yield interaction which was at $15 \mathrm{~cm}$ plant spacing with Gab variety. From Table 3, there was a positive and highly significant correlation between this trait and seed yield $\left(r=0.913^{* *}\right)$. From Figure 1d, the linear component showed a direct proportional relationship between seed yield and protein yield according to the following equation $(\hat{Y}=0.212 \mathrm{X}+5.31)$ which means that an increase of $1 \mathrm{~kg} / \mathrm{ha}$ in seed yield will result in increase in protein yield by $0.212 \mathrm{~kg} / \mathrm{ha}$.

\section{Oil (\%)}

Table 4 displayed the oil percentage that obtained the maximum $15 \mathrm{~cm}$ plant spacing which was $11.81 \%$ and the minimum was at $6 \mathrm{~cm}$ plant spacing which was $7.81 \%$; on the other hand, the optimum oil percentage was at TH85 variety $(11.14 \%)$. The highest Value of oil \% was obtained at $15 \mathrm{~cm}$ plant spacing with TH 85 variety which was $(13.50 \%)$ and the lowest was at $6 \mathrm{~cm}$ plant spacing with Rafidain variety that was $(6.53 \%)$.

\section{Carbohydrate (\%)}

The highest level of carbohydrate percentage was at $6 \mathrm{~cm}$ plant spacing that was $60.91 \%$ and the minimum was at $15 \mathrm{~cm}$ plant spacing which was $58.13 \%$, while the highest rate was TH85 variety which was $59.84 \%$. The optimum rate of interaction between plant spacing and varieties was at $6 \mathrm{~cm}$ plant spacing with TH85 variety that was $61.29 \%$ which was statistically similar to $6 \mathrm{~cm}$ plant spacing with Rafedain variety which was $61.12 \%$ and the minimum was at $15 \mathrm{~cm}$ plant spacing with Rafedain variety that was $57.15 \%$. From Table 3, there was a negative and highly significant correlation between this trait and protein and oil percentages $\left(r=-0.777^{* *}\right.$ and $\left.-0.658^{* *}\right)$. Furthermore, Figure 1e and $f$ showed the linear component revealed an inversely proportional between carbohydrate percentage with protein percentage and oil percentage according to the following equations: $\hat{Y}=-0.63 X+73.1$ and $\hat{Y}=-0.62 X+65.5$ for protein and oil percentages, respectively, which indicate that the reduction of protein percentage and oil percentage one degree, it leads to increase in carbohydrate percentage by $0.63 \%$ and $0.62 \%$, respectively. 


\section{CONCLUSION}

The result showed that the $15 \mathrm{~cm}$ plant spacing has highly positive direct effect of number of primary branches, number of pods per plant, seed yield, protein percentage, protein yield, and oil percentage. Furthermore, the Gab variety gave the top value of number of primary branches, number of pods per plants, seed yield, protein percentage, and protein yield. Then, the interaction between $15 \mathrm{~cm}$ plant spacing and $\mathrm{Gab}$ variety gave optimum seed yield. However, the $6 \mathrm{~cm}$ plant spacing appeared highly carbohydrate percentage; the TH85 variety gave the optimum rate of oil percentage and carbohydrate percentage.

\section{REFERENCES}

Ali, Y., M. A. Haq, G. R. Tahir and N. Ahmad. 1999. Effect of inter and intra row spacing on the yield and yield components of chickpea. Pak. J. Biol. Sci. 2(2): 305-307.

Al-Rawi, K. H. M. 1984. Introduction to Statistics. Dar-Al-Kutoob for Printing and Publication. Mosul University, Mosul. p469.

Bagheri, A., A. Ganjali and M. Parsa. 1997. Chickpea Palnting and Improvement. Press of Mashhad Academic Jihad, Iran.

FAO. 2016. Food and Agricultural Organization of United Nation, Production. Year Book, Roma, Italy.

ICARDA. 1990. Annual Report Food Legume Improvement Program India. ICARDA, India.

Kanooni, H and M. Nematifard. 2013. Effect of sowing time and seeding rate on seed yield and some agronomic traits of two Kabuli chickpea genotypes in autumn sowing in rainfed conditions in Kurdistan province of Iran. Seed Plant Prod. 2(2): 185-200.
SAS. 2005. Statistical Analysis System, Release 82. SAS Institute Inc., NC, USA.

Schwenke, G. D., M. B. Peoples, G. L. Turner and D. F. Herridge. 1998. Doses nitrogen fixation of commercial, dryland chickpea and faba bean crops in north-west new south wales maintain or enhance soil nitrogen. Aust. J. Exp. Agric. 38: 61-70.

Seddique, K. N. M and R. H. Sedgely. 1985. The effect of reduced branching on yield and water use of chickpea in a Mediterranean type of environment. Field Crops Res. 12: 251-296.

Shams, K. S., R. Kobra'e and R. Zangeneh. 2005. Study of the Effect of Planting Density on the Trend of Grain Filling, Yield, and Yield Components of Three Chickpea Varieties Under Kermanshah conditions. Inprocceding of the First National Conference on Pulse in Iran. 20-21 November 2005. Research Center for Plant Sciences. Ferdowsi University of Mashhad, Mashhad. Iran.

Singh, A., R. Prasad and P. K. Sharma. 1988. Effects of plant type and population density on growth and yield of chickpea. J. Agric. Sci. 110(1): 1-4

Singh, G., H. S. Sekhon, G. Singh, G. S. Brar and T. S. Bains. 2011. Effect of plant density on the growth and yield of mungbean (Vigna radiata $\mathrm{L}$. Wilczek) genotypes under different environments in India and Taiwan. Int. J. Agric. Res. 6(7): 573-583.

Steel, R. G. and J. H. Torrie. 1997. Principles and Procedures of Statistics in Scientific Research. $4^{\text {th }}$ ed. McGraw-Hill, New York, USA.

Stieller, R. M., G. D. Hill and B. A. Kenzieb. 1994. Evaluating New Chickpea Genotypes in Cantebury. Vol. 24. Proceedings of Annual Conference Agron Society of New Zealand. p63-66.

Turner, N. C., G. C. Wright and K. H. M. Siddique. 2001. Adaptation of grain legumes (pulses) to water-limited environments. Adv. Agron. 71: 193-231.

Valimohamadi, F., M. Tajbakhsh and A. Saeed. 2009. Effect of planting date and plant density on grain yield, yield and some quality and morphological traits of chickpea (Cicer arietinum $L$ ). J. Sci. Technol. Agric. Nat. Resour. 12(46): 31-40. 